\title{
Information technology literacy: the crucial factor in aged second-career academics' sustainability
}

\author{
Liap-Teck Ong ${ }^{1 *}$, \\ Faculty of Business Design \& Arts, Swinburne University of Technology, Sarawak Camp
}

\begin{abstract}
This study addresses the United Nations (UN) Sustainable Development Goal (SDG) 4's objective to increase the number of adults with relevant skills for employment and decent jobs by looking at the context of aged academics in the domain of digital academia. The literature review reveals that there is a scarcity of research studies related to aged second-career academics. Previous studies which have been carried out on second-career academics in business schools did not address the issue of information technology (IT) literacy. Therefore, this exploratory study aims to contribute to the conversation of increasing and sustaining the number of professionally and capably enriched aged second-career academics in digital academia. A hermeneutic interpretive approach is adopted, covering eight aged second-career academics from various types of higher education institutions across Malaysia. The findings from this study suggest that significant support, appropriate IT development and training programs in enhancing their information technology proficiency and literacy is crucial. The finding suggests that this is particularly pertinent for sustainability with respect to aged second-career academics. The study is expected to enhance the governance of universities with regard to introducing proper orientation and training for supporting and improving the information literacy of aged second-career academics in business schools especially for blended delivery of business education.
\end{abstract}

Keywords: aged second-career academics, employment, information technology literacy, digitised academia, business schools.

\section{Introduction}

The UN SDG4: Quality Education stipulates that by 2030, the goal is "to substantially increase the number of youth and adults who have relevant skills, including technical and vocational skills, for employment, decent jobs and entrepreneurship". Taking this goal in relation to the increasingly aging populace globally, this study subscribes to the concept that aged populace needs to be gainfully employed. One of the sectors which can offer such opportunities to the aged is the academic sector. The increasing demand for business education at tertiary level has increased the demand of academics with practical experience in industry prior to their assuming the role of business academics. These academics are classified as secondcareer academics (Larocco \& Bruns, 2006) and this study focuses on aged academics of 55 years old and beyond. They are, by definition, from the generation of baby-boomers. Given that they are not digital natives and working in academia, which is increasingly digitised, there is a need to know the pertinent factor that would sustain their academic career, which fully utilises their relevant skills and knowledge in management and entrepreneurship. Furthermore, there is evidence that academics with relevant practical and professional experiences are in short supply; hence, this study will also look at how to sustain the supply and retention of such aged second-career academics.

Without such support, there is a possibility that these second-career academics may underperform, produce insufficient output, make limited contributions, and not able to last long enough in academia. Therefore, the findings from this study will address the UN SDG4 in regard to "increasing the number of adults who have relevant skills for employment and decent jobs".

\section{Literature review}

The literature review covers two domains related to the focus of this study, namely, business education and digitisation of academia.

\section{Business education}

Initially, business schools in the USA adopted a vocational mode of teaching, and the business faculties were staffed by business practitioners with only a few academic staff members with $\mathrm{PhD}$ qualifications (Bennis \& O'Toole, 2005; Clinebell \& Clinebell, 2008; Cornuel, 2007; Cornuel \& Hommel, 2012; Cotton, McKenna, Van Auken \& Meuter Au, 2001; Ford,

\footnotetext{
*Corresponding Author: long@swinburne.edu.my
} 
Harding \& Learmonth, 2010; Grey, 2002). However, since the 1950s, with the publication of the report, Higher Education for Business (Gordon \& Howell, 1959) and the book, The Education of American Businessmen (Pierson, 1959), there had been a drastic institutional change in the nature of business education and staffing in business schools (Cotton et al., 2001). Business schools began to adhere to the call to adopt a more scientific model similar to the physical sciences and economics. The scientific model as advocated by the Gordon and Howell report resulted in the faculty members of business schools being staffed by people holding $\mathrm{PhD}$ qualifications beginning 1960, which introduced a scholarly mode of teaching (Fourcade \& Khurana, 2013; Grey, 2004; Khurana \& Penrice, 2011; Khurana \& Spender, 2012; Pfeffer \& Fong, 2002, 2003, 2004; Starkey, Hatchuel \& Tempest, 2004; Starkey \& Tempest, 2005, 2009). This scholarly mode of teaching played a strong advocating role in favour of the legitimation of business schools within institutions of higher education. Nevertheless, there were concerns or even doubts about the legitimacy and relevance of business schools in the scholarly context of institutions of higher education. This led the Association to Advance Collegiate Schools of Business (AACSB International) to sponsor a study on business schools in the USA by Porter and McKibbin in 1988 (Boyle, 2004; Cotton et al., 2001).

Porter and McKibbin's study reviewed the role of business schools in the USA. It culminated in the publication of a report addressing key issues concerning business schools, such as the need for strategic planning, a clear role for business schools, curriculum and development of faculty, accreditation of lifelong learning, and future collaboration among industry, AACSB, and business schools (Cotton et al., 2001; DeAngelo, DeAngelo, \& Zimmerman, 2005; Engwall,

2007). One of the issues that the study covered was the legitimacy of business schools within a university setting. Another issue was the content and curriculum of the business subjects taught in business schools in the USA.

\section{Digitisation of academia}

Education is increasingly a globalised business venture. As such, for efficiency and accessibility, academia at tertiary level is increasingly digitised (Tang \& Chaw, 2016). For example, the incursion of blended delivery, e-delivery and digitised learning management systems are adopted and incorporated as a means to increase teaching and learning efficiency and effectiveness. (Ahmad, Madarsha, Zainuddin, Ismail, Nordin \& Nordin, 2010; Selwyn, 2007; Stahl, 2004) Moreover, this is to prepare the graduates to be career ready in the digitised working environment in the corporate world. From the business education's perspective, the digitisation of teaching and learning in business courses is to equip graduates with the skills and expertise they need in new technologies so that they are not only employable but thrive in the highly digitised business environment including e-entrepreneurship and e-commerce (Coccoli, Guercio, Maresca, \& Stanganelli. 2014; Selwyn, 2007).

This leads to the digitisation of academia with respect to teaching, learning and publication. There is a plethora of digital appliances, systems, methods, processes, software, hardware and tools to conduct teaching, learning and publication. There is even a prediction that most tertiary teaching and learning will take place online, with little face-to- face instruction or interaction anymore (Robertson and Komlenjenovic, 2016). Academics are required to embrace digital technologies such as online learning, student feedback and referencing systems as part of their workload model. Online publication has become the norm with journals being digitised, enabling citations to scholarly work to be monitored and measured using software tools such as Google Scholar and Scopus. Other avenues such as blogs and social media facilitate interaction with students and learners, unrestricted by location and time. In view of the progressive emergence of these technologies within academia, there is a corresponding increase in research on assessing the impact of digitisation of academia on the academics. However, very few studies focus on aged second-career academics and the digital academia.

\section{Research Objectives}

It is the aim of this proposed research to offer insights into the factors affecting the performance of aged second-career academics in business schools due to the digitisation of academia. This research, therefore, explores how information technology literacy affects the sustainability of aged second-career academics.

\section{Research Approach and Method}

\section{Approach}

The research objective mentioned above requires a detailed investigation of specific individual experiences with information technology deplored in a digital academy. Since the focus is on investigating individual experiences, the research approach will be aligned with the hermeneutic-interpretive research paradigm (Guba \& Lincoln, 1994; Van Manen, 1990).

\section{Data Collection Method}

Given the specific focus and objectives of the proposed study, the semi-structured in-depth interview is adopted as the appropriate method for data collection. The interviews incorporated provisions for accommodating contributions from the participants, made possible through semi-structured interviews. 
Due to the purposeful sampling adopted in this study, all the participants have at least 25 years of working experience in industry excluding their years in academia, which qualifies them as aged second-career academics. This heterogeneity provided a wide range of perspectives in the data. This is an element of research quality in interpretive research (Vähäsantanen \& Saarinen, 2012). The profile of the participants is presented in the table below.

Table 1 Participants’ Background

\begin{tabular}{lll}
\hline Participants & Years in Industry & Field of Practice \\
\hline S1 & 20 & Banking \\
\hline S2 & 25 & Banking \\
\hline S3 & 30 & Accounting \\
\hline S4 & 30 & Human Resource Management \\
\hline S5 & 28 & Logistics \\
\hline S6 & 20 & Manufacturing \\
\hline S7 & 26 & Accounting \\
\hline P8 & 14 & International Business
\end{tabular}

\section{Analysis}

\section{Challenges posed by lack of IT literacy}

Based on the following units of meanings extracted from the interviews conducted, it can be conceptualised that there is a challenge posed by the lack of IT literacy for these aged second-career academics. The challenges appear to originate from encountering difficulties in dealing with the information and communication technology (ICT) used in institutions of higher education. Their experience seems consistent with the studies on the challenges faced by academics due to the impact of ICT on higher education. Sample extracts from their narratives are provided below:

“So because of my background, I am not computer literate. ”S1

"Another factor is that my age is also I am not that young anymore, it's almost like the end of my career. .. It's an issue." S6

Several factors could possibly contribute to their lack of IT literacy, namely their previous working experience in industry which may not require them to possess the degree of proficiency in information technology. However, in the current environment of digital academia, the extent of reliance on information technology in the domains of learning, teaching and research has also increased. Furthermore, in academia, these aged second-career academics have to be hands-on. This new environment requires them to be proficient with IT itself. This is unlike their previous experience in the industry when they had other administrative and secretarial staff to assist them in IT related tasks such as e-filing, e-reporting and presentation. This can be discerned from the narratives cited below.

"Ok, the clerical part. . I have been, in fact, before I quit the industry, my last post was a general manager of one of the company. . . when you are in the industry, you have your secretary, you have your clerk to do job for you but when come to education, there are some part of clerical job which you are not very familiar with then that is a process of adaptation." S1 
Secondly, the students are digital natives, and their IT proficiency could be more advanced than the aged second-career academics. The aged second-career academics are employed mainly because of their real-world business and professional experience, and as P18 commented, they are not very "hands-on" in using computers. However, these aged second-career academics need to be proficient in IT to facilitate effective interaction and dialogue with students under their care.

"I have real challenges when it come to do things on the computer, you must know that I am in the baby boomer group, we are not very hands on and very good in using computer, it come much later in my career, ok? So I find that very challenging." S4

Thirdly, being new to academia, they need to unlearn and re-learn new skills such as teaching, curriculum design, class management, learning management system, research and publication. These activities are heavily laden with IT components and there is a need for them to upskill their IT literacy and proficiency. Two examples of the narratives are as shown below:

"In fact, I am still learning from my students, I am learning from them because I belong to the older generation, my era is not the IT age, technology is not that advanced yet. Excel, Words, internet is not there, we only learn it maybe only after about 40, 50 around maybe 5, 10 years back, so we are not as advance as those youngsters, those school leavers for example talking about those teenagers, they can teach you better because they know their computer better than you, the IT knowledge, they are better than you, "S3

"So it was a learning experience for me to come up with the course material, but also in my communication with students over the learning management system, you know. "S5

"when I first joined the academic, I have to learn up to especially like lecture notes, how to prepare power point, we even have to do the so call, the er the online quiz, right, which I have to ask the students to go online to do the quiz which was given to them. So, er and er those are the things which I don't have to do when I was in private sector. "S7

\section{Overcoming IT literacy}

As discussed previously, this study explores the challenges in IT literacy encountered by aged second-career academics. However, the study also reveals the avenues in which their IT literacy deficiency is being addressed in the participating institutions of higher education.

Firstly, the participants highlighted the support these aged second-career academics received to overcome their IT inadequacy. The study reveals positive aspects of institutional support through the provision of IT training and peer assistance from their colleagues, particularly from fellow academics who are digital natives.

"So it's quite difficult for me to understand some program, program that needs practice. So this is where friends, colleagues come in and help, in terms of how to complete the report. Of course I am not going to ask him or her to do the whole way, they will teach me." $S 1$

"Oh when I just join this university, I actually went through 1 week ....various aspects ere r as a lecturer what should I know, how to behave and even when I handle those students in the in the web site, the chat forum itself, how should I approach ere $r$ them er the kind of language that we are supposed to use, because we are a very unique kind of a, er er delivery system, er online system, "S6

Secondly, the intellectually stimulating environment in institutions of higher education provides support in itself. For the aged academics, the learning process may be adversely affected by their age. However, given that being an academic is an intellectually stimulating endeavour, the need to engage with thinking and the related cognitive activities probably account as an added advantage. This institutional support comes in the form of a collegial and empathetic environment from colleagues and university management, and assistance from first-career academics in research work involving research software for surveys, data collection, interpretation, quantitative and qualitative analysis, thesis compilation and presentation

"I think the university support us in the facilities, these are the library facilities, the software, some of the software we used, funding or research grant that we have applied, these are the things that they support you. "S2

Thirdly, the adoption of user-friendly learning management systems, such as Canvas or Blackboard, supplemented with technological support and training helps to address the problem of IT literacy deficiency of these aged second-career academics. In the host university in which part of this study was conducted, there is a technical team specially set up to ensure proficiency in the use of the learning management system. Furthermore, there are continuous seminars and training sessions conducted to assist aged second-career academics in the use of IT in learning, teaching and research.

"For the opportunity because I think in terms of the effort by the university is tremendous. there are workshops, for you to polish your teaching skills, whatever and so on, e-learning, things like that, I think all are there just a matter of whether you have the time to go through them, I think I think I have e to commend the university for that. ... So I have had actually 
assistance from my colleagues, in the sense that where I need help, especially academic orientated stuff so they assist me." S8

\section{Discussion}

This study reveals that the issue of information technology literacy for these second-career academics is precipitated by their age, lack of exposure to IT and career transition to academia which is increasingly digitised. The study also discovers that to some extent, the adverse impact of lack of IT literacy is mitigated by the institutional support, collegiality of the fellow academics who are digital natives and the user friendliness of the software adopted at the institutions of higher education participating in this study.

The study supports the findings of other research that claim that the digitisation of academia does indeed pose issues and challenges, particularly for the second-career academics. However, this study reveals some of the avenues which have been implemented to overcome these challenges. The positive aspect of institutional support through the provision of IT training and peer assistance is necessary for non-digital natives. For the aged academics, the learning process may be adversely affected by their age. However, given that being an academic is an intellectually stimulating endeavour, the need to engage with thinking and the related cognitive activities probably account as an advantage. Another factor is the user-friendliness of the online learning management systems such as Blackboard and Canvas. The mastering of the learning management system is apparently an added mechanism in facilitating the aged academics in overcoming the digital divide.

However, it must be recognised that currently, for brick-and-mortar institutions of higher education, the degree of blended delivery of courses for business education is still in its infancy. As it stands, at present, the percentage of online delivery of courses in Malaysia is not more than 30\% for the units accredited by the Malaysian Qualifying Authority in regard to higher education. This, to some extent, means that the majority of the teaching is conducted on a face to-face basis. This probably mitigates the impact of IT inadequacy in the aged second-career academics. However, the trend is for an increase rather than a decrease in the e-delivery of tertiary education online. Therefore, university management should take steps to enhance the current supporting facilities which help to mitigate the IT literacy deficiency of the aged second-career academics. Firstly, university management should recognise and acknowledge that the issue does exist especially among aged academics. Universities can help by creating opportunities for specific training needs in IT for aged second-career academics, and specifically, in online research and publication. There are various areas for training, and these could include teaching approaches for both online and face-to-face courses, use of learning management system, strategies for e-forum discussions, online grading of assignments, e-publication and etiquette in e-communication.

This study also provides a glimpse of the significance of collegiality in assisting the acquisition of information technology by the aged second-career academics. This is significant because although there is an aggressive ingress of managerialism into academia, coupled with the increasingly corporatisation of academia, the level of collegiality in academia, as discovered in this study actually contribute to the assimilation of aged second-career academics into academia. Perhaps, for these aged second-career academics, the previous experience of a more stressful and competitive career in industry has helped them to better appreciate the collegiality in academia. This, in turn, translates into a better learning environment for them to acquire the necessary literacy in information technology. Therefore, university managements, particularly business schools in the strive for better ranking and research output, might review their strategy in accommodating these aged second-career academics in academia through a review of the prevailing support and collegiality in their respective institutions.

\section{Conclusion}

Universities need to recognise aged second-career academics as a group of academics with special needs, particularly with IT literacy. Using them merely to fill vacant teaching positions, without offering well-targeted support programs in IT literacy would not be advantageous in the long run. This study focused on the lack of IT literacy for aged second- career academics in business schools in Malaysia, working at the tertiary level of education. However, IT literacy may be only one of the factors affecting the full utilisation of the skills and expertise for the aged second-career academics. Nevertheless, in response to UN SDG4 which emphasises the need to "substantially increase the number of ... adults who have relevant skills, including technical and vocational skills, for employment, decent jobs", this study suggests that overcoming the deficiency in IT literacy of aged second-career academics is one of the key actions that needs to be taken for meaningful and useful employment for aged second-career academics. 


\section{REFERENCES}

1. Ahmad, T., Madarsha, K., Zainuddin, A., Ismail, N., Nordin, M. \& Nordin, M. (2010). Faculty's acceptance of computer-based technology: Cross-validation of an extended model. Australasian Journal of Educational Technology, 26(2), Australasian Society for Computers in Learning in Tertiary Education. Retrieved February 17, 2020 from https://www.learntechlib.org/p/44249/.

2. Bennis, W. G., \& O'Toole, J. (2005). How business schools lost their way. Harvard business review, 83(5), 96104. Boyle, M.-E. (2004). Walking our talk: Business schools, legitimacy, and citizenship. Business \& Society, 43(1), 37-68.

3. Clinebell, S. K., \& Clinebell, J. M. (2008). The tension in business education between academic rigor and realworld relevance: The role of executive professors. Academy of Management Learning \& Education, 7(1), 99-107.

4. Cornuel, E. (2007). Challenges facing business schools in the future. Journal of Management Development, 26(1), 87-92.

5. Cornuel, E., \& Hommel, U. (2012). Business schools as a positive force for fostering societal change. Business and Professional Ethics Journal, 31(2), 289-312.

6. Cotton, C. C., McKenna, J. F., Van Auken, S., \& Meuter, M. L. (2001). Action and reaction in the evolution of business school missions. Management Decision, 39(3), 227-233.

7. DeAngelo, H., DeAngelo, L., \& Zimmerman, J. L. (2005). What's really wrong with US business schools. Social Science Research Network.

8. Engwall, L. (2007). The anatomy of management education. Scandinavian Journal of Management, 23(1), 4-35.

9. Ford, J., Harding, N., \& Learmonth, M. (2010). Who is it that would make business schools more critical? Critical reflections on critical management studies. British Journal of Management, 21(s1), s71-s81.

10. Fourcade, M., \& Khurana, R. (2013). From social control to financial economics: The linked ecologies of economics and business in twentieth century America. Theory and Society, 42(2), 121-159.

11. Grey, C. (2002). What are business schools for? On silence and voice in management education. Journal of management education, 26(5), 496-511.

12. Grey, C. (2004). Reinventing business schools: The contribution of critical management education. Academy of Management Learning \& Education, 3(2), 178-186.

13. Khurana, R., \& Penrice, D. (2011). Business education: The American Trajectory. Business Schools and their Contribution to Society, 3-15.

14. Khurana, R., \& Spender, J. (2012). Herbert A. Simon on what ails business schools: More than 'a problem in organizational design'. Journal of Management Studies, 49(3), 619-639.

15. Larocco, D. J., \& Bruns, D. A. (2006). Practitioner to professor: an examination of second career academics' entry into academia. Education, 126(4), 626-639.

16. Pfeffer, J., \& Fong, C. T. (2002). The end of business schools? Less success than meets the eye. Academy of Management Learning \& Education, 1(1), 78-95.

17. Pfeffer, J., \& Fong, C. T. (2003). Assessing business schools: Reply to Connolly. Academy of Management Learning \& Education, 2(4), 368-370.

18. Pfeffer, J., \& Fong, C. T. (2004). The business school 'business': Some lessons from the US experience. Journal of Management Studies, 41(8), 1501-1520.

19. Robertson S and Komlenjenovic J. (2016) Unbundling the university and making higher education markets. In: Verger A, Lubienski C and Steiner-Kamsi G (eds) The Global Education Industry. London: Routledge, 211-227.

20. Selwyn, N. (2007). The Use of Computer Technology in University Teaching and Learning: A Critical Perspective. Journal of Computer Assisted Learning, 23(2), 83-94. Wiley. Retrieved February 17, 2020 from https://www.learntechlib.org/p/99838/.

21. Stahl B. (2004) E-teaching - the economic threat to the ethical legitimacy of education? Journal of Information Systems Education15, 155-162.

22. Starkey, K., \& Tempest, S. (2005). The future of the business school: Knowledge challenges and opportunities. Human Relations, 58(1), 61-82.

23. Starkey, K., \& Tempest, S. (2009). The winter of our discontent: The design challenge for business schools. Academy of Management Learning \& Education, 8(4), 576-586.

24. Starkey, K., Hatchuel, A., \& Tempest, S. (2004). Rethinking the business school. Journal of Management Studies, 41(8), 1521-1531.

25. Vähäsantanen, K., \& Saarinen, J. (2012). The power dance in the research interview: manifesting power and powerlessness. Qualitative Research, 1468794112451036.

26. Van Manen, M. (1990). Researching Lived Experience: Human Science for an Action Sensitive Pedagogy. New York: Suny Press. 